\title{
1. Looking back on 30 years of transition - and looking 30 years ahead Robert Holzmann ${ }^{1}$
}

\subsection{TRANSITION PARALLELED BY EUROPEAN INTEGRATION}

With the fall of the Iron Curtain, a long and difficult, yet unavoidable journey of transition began for the countries of Central, Eastern and Southeastern Europe (CESEE): a transition from centrally planned state socialism to modern democracies, market mechanism and capitalism. Unlike many Asian economies that adopted a more gradual approach, the CESEE countries applied a 'shock therapy' of rapid change. This meant that the initial economic tremor took its toll in the 1990s, in the form of deep recessions, soaring prices, currency depreciations, bank failures and high levels of unemployment (see Holzmann et al. 1995). The CESEE countries' intrinsic strengths came to the fore only later, as privatized industries were restructured, and reforms were implemented. The capital and foreign investment thus attracted propelled productivity and competitiveness, which in turn boosted economic growth.

This unprecedented social, political and economic metamorphosis was paralleled and supported by the process of European reunification. Today, 11 former Eastern bloc countries are united with their former ideological opponents under one European flag, and some of them also under the umbrella of a common currency. While being emancipated and self-confident partners, the European Union (EU) countries share democratic and legal values as well as institutional principles. We must point out that the European Union constitutes a crucial stabilizing anchor and, of course, provides budgetary support even for countries that are not yet members of the European Union.

\subsection{SUCCESSFUL REFORMS AND ONGOING INTEGRATION STEPS}

Catalyzed in several cases by prospective EU membership, reforms in CESEE eventually started to work. The CESEE economies established a record of 
significant economic growth and convergence as CESEE became one of the world's fastest-growing regions in the first half of the 2000s. Then, however, with the outbreak of the global financial crisis, the blessing of ever closer trade and financial linkages with Western Europe turned into a major challenge for CESEE. The economic shock quickly spilled over and harshly hit most of the CESEE countries despite their heterogeneity. Countries where the strong - and, in several cases, excessive - pre-crisis expansion had been driven by unsustainable levels of consumption and borrowing were affected the most.

In this context, we should stress the crucial role of the so-called Vienna Initiative, to which Austrian authorities also made significant contributions. At the peak of the crisis, all relevant stakeholders came together to coordinate their actions and thus prevent the imminent risk of a large-scale and chaotic withdrawal of cross-border bank groups from the CESEE region, which could have triggered massive systemic bank crises (see Nowotny et al. 2019).

It goes without saying that the three decades of transition have not been just a walk in the park. Despite great and respectable achievements, the transformation path has been perceived by many as too long, too difficult and too painful. Unfulfilled promises and unrealistic expectations of the transformation process have had various social, economic and political ramifications. While their form and extent vary from country to country, such consequences are reflected to an unforeseen extent in nostalgia and mounting attacks against democratic institutions and liberal values.

\subsection{BUILDING BLOCKS AND STUMBLING BLOCKS FOR THE NEXT 30 YEARS}

Let us now turn to the major challenges in CESEE when looking ahead. The national populism that has increasingly been taking hold in the CESEE countries resonates particularly well with those who feel 'lost in transition'. While the CESEE countries have caught up impressively toward Western European income levels over the last 30 years, income gaps persist, some of them substantial. Moreover, since economic growth has slackened as a legacy of the global financial crisis, convergence has slowed down. Therefore, it is of the utmost importance for the region to continue fostering convergence by spurring inclusive economic growth. To increase dampened productivity and capital formation, efforts should focus particularly on investments in infrastructure (including digitalization), human capital endowment and innovation, but also on improving the institutional, legal and business environment that supports a dynamic entrepreneurial sector in a Schumpeterian sense.

This is all the more important as potential growth will additionally be strongly limited in the medium to long run by adverse demographic developments, which pose another big challenge for the CESEE countries. In most 
of the region, the population is shrinking, mainly due to low life expectancy and low birth rates, but also to negative net migration. Whatever the causes, one important answer to future challenges will be to keep older people in the workforce. Fortunately, the trend toward earlier retirement has been reversed over the last decade, but more needs to be done in all countries concerned (see Gal and Radó 2019). Reforms have markedly improved the sustainability of public pension systems, but old-age poverty continues to be a problem in some CESEE countries, particularly for women. Pension reform is, perhaps, a trial and error process, a reminder of the famous quote by Friedrich von Hayek: 'The curious task of economics is to demonstrate to men how little they really know about what they imagine they can design' (von Hayek 1988, p. 76). Indeed, designing a stable pension system without jeopardizing people's confidence requires both science and art.

Whereas CESEE pensioners are staying in their countries, people of working age are emigrating. And even worse, the first to leave are the young and the most skilled, which threatens public health and productivity growth in their home countries. The challenge for CESEE countries with high emigration is to turn this brain drain into a brain gain by attracting people back or recruiting immigrants from third countries. The good news is that economic history provides numerous examples of emigration countries managing to become destinations of re-migration. Since economic development only becomes a pull factor when a certain minimum income threshold is reached, however, good governance and specific policies that improve people's quality of life will be essential to win and keep talents (see European Commission 2018).

Good governance - an elastic concept, admittedly - applies not only to individual countries but also to European institutions. Indeed, European economic integration proceeds between the poles of deepening and enlargement, as we have seen from the recent disagreement about the timing of accession talks with candidate countries before securing the EU's absorption capacity. The Brexit experience suggests that not even the direction of deepening and enlargement can be foreseen with precision. 'Prediction is very difficult, especially about the future' - apparently, this truism of Niels Bohr also applies to the negotiations among the EU Member States about the deepening of Economic and Monetary Union (EMU). A resilient common currency needs integrated markets. Completing the banking union and developing a capital markets union seems less controversial than the creation of a fiscal union. Indeed, the example of the United States (US) - which is not a perfect optimal currency area either - suggests that most of the interregional risk-sharing necessary in a common currency area takes place via financial markets and not via budgetary transfers. Still, the EU budget is dwarfed by the US federal budget. Moreover, fiscal flows lead and facilitate financial flows - not least via safe 
assets - and thus add a qualitative component to their quantitative contribution to risk-sharing.

Whatever the outcome of this debate, the development and integration of financial markets is the order of the day, both in EMU and in CESEE. Without neglecting the important role of banking in providing finance, particularly to medium-sized businesses, it will be crucial to deepen capital markets.

With the benefit of hindsight, and when drawing lessons from the global financial crisis that then morphed into the so-called sovereign European debt crisis, some missing pieces of the euro area architecture were revealed, such as the lack of a banking union. The establishment of such a union, whose first pillar - the Single Supervisory Mechanism (SSM) - became fully operational in 2014, has probably constituted the most important institutional innovation since the launch of the euro in 1999. For non-euro area EU countries, such as Bulgaria and Croatia, that are preparing to become members of the euro area, this means that they must not only fulfil the Maastricht criteria in a sustainable manner before being able to adopt the euro. Additionally, given that EMU has changed since the crisis, they are also expected to enter into close cooperation with the SSM before introducing the euro (see Backé and Dvorsky 2018). It has long been acknowledged that there is no 'one size fits all' approach to how soon countries should give up their independent monetary policy - a decisive macroeconomic tool - in favour of joining monetary union. Also, public support for such a move differs across CESEE countries, although it has become increasingly favourable.

\subsection{CONCLUSIONS}

Despite several setbacks and various shortcomings, the CESEE countries deserve our deep respect for their successful transition from dysfunctional command economies to flourishing market economies. However, transition - in the sense of adjustment to a changing and challenging environment - is a permanent process. There are always new challenges ahead; not only in CESEE, but all over Europe and all over the world. We will have to transit to - or through - ageing societies, low carbon economies, digital finance and further economic, financial and monetary integration. Facing all these transitions, it will be key to cooperate in the spirit of the European Union's official motto, 'United in diversity'. Precisely in this vein, we should all collaborate within Europe to be able to better cope with many of the challenges that we will face. We can - to give but one example - help each other to develop financial markets by sharing our experience with products, regulation and supervision, building on the support of international financial institutions, such as the International Monetary Fund and the World Bank. If we all sustain our 
commitment, we can do our bit in making sure that the success story of the past decades in CESEE will continue for many years to come.

\section{NOTE}

1. Andreas Breitenfellner and Tomáš Slačík, of the Oesterreichische Nationalbank's staff, contributed to this chapter.

\section{REFERENCES}

Backé, P. and S. Dvorsky (2018), 'Enlargement of the Euro Area toward CESEE: Progress and Perspectives', Focus on European Economic Integration Q3/18, 43-56.

European Commission (2018), 'Addressing Brain Drain: The Local and Regional Dimension', Report by the European Committee of Regions, available at https://cor .europa.eu/en/engage/studies/Documents/addressing-brain-drain/addressing-brain -drain.pdf (accessed on 31 January 2020).

Gal, R.I. and M. Radó (2019), 'Labor Market Participation and Postponed Retirement in Central and Eastern Europe', in R. Holzmann, E. Palmer, R. Palacios and S. Sacchi (eds), Progress and Challenges of Nonfinancial Defined Contribution Pension Schemes: Addressing Marginalization, Polarization, and the Labor Market (Volume 1), Washington, DC: World Bank Group, 371-398.

Holzmann, R., J. Gács and G. Winckler (1995), Output Decline in Eastern Europe: Unavoidable, External Influence or Homemade?, Dordrecht: Kluwer Academic Publishers.

Nowotny E., D. Ritzberger-Grünwald and H. Schuberth (2019), How to Finance Cohesion in Europe?, Cheltenham, UK and Northampton, MA, USA: Edward Elgar Publishing.

von Hayek, F.A. (1988), The Fatal Conceit: The Errors of Socialism, London: University of Chicago Press. 